\title{
Study of Matrix Gla Protein G-7A and T-138C Gene Polymorphisms in Patients with Type 2 Diabetes Mellitus
}

\author{
Fulya Yukcu ${ }^{*}$, Tammam Sipahi ${ }^{2}$, Sibel Guldiken ${ }^{3}$, Serhat Hüseyin $^{4}$, Betul Ekiz Bilir ${ }^{5}$
}

\begin{abstract}
Objectives: Type 2 diabetes mellitus is a major risk factor for aortic calcifications and cardiovascular diseases. Gamma-carboxyglutamic acid (G-7A) protein has a significant role in control of the process of calcification. The purpose of this study was to investigate the role of G-7A and T-138C gene polymorphisms in development of aortic calcification and cardiovascular disease in patients with type 2 diabetes mellitus.

Material and Methods: The study included 120 patients with type 2 diabetes mellitus and 134 control group. G$7 \mathrm{~A}$ and $\mathrm{T}-138 \mathrm{C}$ gene polymorphisms were identified using polymerase chain reaction and followed by restriction fragment length polymorphism methods.

Results: The G-7A genotype distribution in patients with type 2 diabetes mellitus $\mathrm{AA}=10.8 \%, \mathrm{GA}=41.7 \%$ and $\mathrm{GG}=47.5 \%$ did not significantly differ from those in control group $\mathrm{AA}=15.7 \%, \mathrm{GA}=48.5 \%$ and $\mathrm{GG}=35.8 \%$ $(\mathrm{P}=0.146)$. The $\mathrm{T}-138 \mathrm{C}$ genotype distribution in patients with type 2 diabetes mellitus $\mathrm{CC}=8.4 \%, \mathrm{CT}=40.8 \%$ and $\mathrm{TT}=50.8 \%$ were also not significantly different from those in control group $\mathrm{CC}=3.7 \%, \mathrm{CT}=39.6 \%$ and $\mathrm{TT}=56.7 \%(\mathrm{P}=0.259)$. On the other hand; age, fasting blood glucose, cholesterol, high density lipoprotein cholesterol and low density lipoprotein cholesterol as expected were significantly differed between the patientcontrol groups $(\mathrm{p}<0.05)$.

Conclusion: This patient-control study shown that G-7A and T-138C gene polymorphisms of gammacarboxyglutamic acid protein are not genetic risk factors for type 2 diabetes mellitus
\end{abstract}

Key words: Gamma-carboxyglutamic acid protein, G-7A gene polymorphism, restriction fragment length polymorphism, T-138C gene polymorphism, Type 2 diabetes mellitus

\section{Introduction}

Diabetes mellitus is an important health problem due to the illness itself and its life threatening complications. Type 2 diabetes mellitus is a disease characterized by insulin resistance and cell failure leading to elevated blood glucose levels (1). Aortic calcifications and cardiovascular diseases (CVD) are an important factor in the pathophysiology of type 2 diabetes mellitus (2).

In various tissues, tissue calcification is expected to be high due to high extracellular fluid concentrations of calcium and phosphate ions (3). Gamma-carboxyglutamic acid proten (MGP), which is vitamin $\mathrm{K}$ dependent calcium/phosphate binder protein and as the first protein known to act as a calcification inhibitor in vivo, takes control of the process of calcification $(4,5)$. The human MGP gene is located on the short arm of chromosome 12 and comprises 5 exons (12p12.3). This gene has 4 transcripts. We were taken as a reference MGP-004 in our study. (Transcript ID: ENST00000228938).

(http://www.ensembl.org/Homo_sapiens/Tra nscript/Summary?db=core;g=ENSG00000111341;r=1 2:14881181-14885926;t=ENST00000228938).
In vitro studies suggest that the gene encoding MGP has several single nucleotide polymorphisms (SNPs) in its promoter and coding regions (5). We selected two common SNPs on the MGP gene promoter

G-7A (http://www.ncbi.nlm.nih.gov/projects/ SNP/snp_ref.cgi?rs=1800801)

and

T-138C (http://www.ncbi.nlm.nih.gov/projects/ SNP/snp_ref.cgi?rs=1800802).

G-7A gene polymorphism, located in the promoter region of the MGP gene and characterized by replacing of guanine with adenine (G/A). T-138C gene polymorphism, has located in the promoter region of the MGP gene which is characterized by replacing of the thymine/cytosine $(\mathrm{T} / \mathrm{C})$. Various environmental and genetic risk factors have been considered to contribute in increasing the effects of these polymorphisms such as geographic, socioeconomic and racial features. In some studies, MGP gene polymorphisms were shown to be associated with arterial calcification or with CVD, 
while in others, no association between MGP gene polymorphisms and arterial calcification or with CVD were found $(6,7)$.

The purpose of this study was to investigate G-7A and T-138C gene polymorphisms of gammacarboxyglutamic acid protein in patients with type 2 diabetes mellitus and the possible role of these genes in the development of aortic calcification and CVD.

\section{Material and method}

The study included 120 patients with type 2 diabetes mellitus (55,8\% men and 44,2\% women) and 134 control group (45,5\% men and $54,5 \%$ women). The mean age of the patients were $(62.76 \pm 11.15)$ and the mean age of the control group were (51. $10 \pm 10.78$ ), respectively. Patients who had been diagnosed with type 2 diabetes mellitus were included to the y. In the control group type 2 diabetes mellitus, ischemic heart disease (IHD), peripheral arterial disease (PAD), stroke and any chronic illness patients were not included in this study. All participants gave informed consent that was approved by the local ethics committee.

\section{DNA isolation}

Deoxyribonucleic acid (DNA) was isolated from peripheral blood, containing ethylene-diamine tetra-acetic acid (EDTA) as an anticoagulant, by e.Z.N.A. (EaZy Nucleic Acid Isolation) blood DNA kits (BOGA, Istanbul, Turkey). DNA purity and quality were assessed by absorbance values in spectrophotometer (Shimadzu UV-1208). The ratio of optical density (O.D.) at $260 \mathrm{~nm}$ to O.D. at $280 \mathrm{~nm}$ was found about 1.8 for all samples. DNA bands were observed by ethidium bromide-stained $0.8 \%$ agarose gel electrophoresis (Figure 1).

\begin{tabular}{|lllllll|}
\hline 1 & 2 & 3 & 4 & 5 & 6 & 7 \\
\hline
\end{tabular}

Figure 1. The ethidium-bromide stained $0.8 \%$ agarose gel of representative DNA samples.

\section{Genotyping of MGP G-7A gene polymorphism}

To determine the MGP G-7A gene polymorphism of the Type 2 diabetic and the control groups, a genomic DNA fragment on promoter region of the MGP gene was amplified by polymerase chain reaction (PCR) in a $25 \mu \mathrm{l} \mathrm{PCR}$ reaction mixture containing $100 \mathrm{ng}$ of DNA, dNTP (0.2 mM of each), upstream CTAGTTCAGTGCCAACCCTTCCCCACC-3' and downstream

\section{TAGCAGCAGTAGGGAGAGAGGCTCCCA-3'}

primers (3,5 pmol), 1XTaq Buffer (10 mM Tris- $\mathrm{HCl}$, $\mathrm{pH} 8.3,50 \mathrm{mM} \mathrm{KCL}), 2 \mathrm{mM} \mathrm{MgCl} 2$ and $1.25 \mathrm{U}$ of Taq DNA polymerase (Fermentas Life Sciences).

Amplification were performed with 3 minute of denaturation at $94^{\circ} \mathrm{C}$, followed by 30 cycles with denaturation for 30 second at $94^{\circ} \mathrm{C}$, annealing for 1 minute at $64^{\circ} \mathrm{C}$, and extension for 1 minute at $72^{\circ} \mathrm{C}$, followed by 5 minute of extension at $72^{\circ} \mathrm{C}(8)$. The PCR products were electrophoresed in $2 \%$ agarose gels, and visualized under UV light Trans-illumination (ETX-F26.M) by ethidium bromide staining. $5 \mu \mathrm{l}$ of PCR product were digested with $5 \mathrm{U}$ of the restriction enzyme NcoI in 1XM Buffer $(10 \mathrm{mM}$ Tris- $\mathrm{HCl} \mathrm{pH}$ 7.5, $10 \mathrm{mM} \mathrm{MgCl2,} 1 \mathrm{mM}$ Dithiothreitol and $50 \mathrm{mM}$ $\mathrm{NaCl}$ ) for 3 hours at $37^{\circ} \mathrm{C}$. The restriction digest products were visualized by UV light transillumination (ETX-F26.M) after electrophoresis on a $3 \%$ agarose gel and ethidium bromide staining (Figure 2).

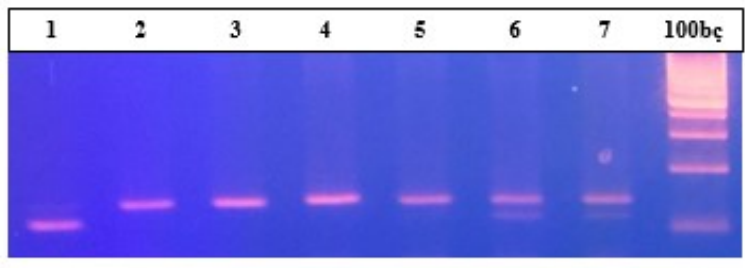

Figure 2. Ethidium bromide stained 3\% agarose gel of representative PCR digested products of G-7A gene polymorphism shows the AA genotype (lane 1), the GA (lane 6,7) and the GG genotype (lane 2, 3, 4 and 5); lane $100 \mathrm{bp}$ is a size marker.

\section{Genotyping of MGP T-138C gene polymorphism}

MGP T-138C gene polymorphism was identified with PCR and followed by restriction fragment length polymorphism (RFLP) with the restriction enzyme BsrSI. $25 \mu \mathrm{l}$ PCR reaction mixture containing $200 \mathrm{ng}$, dNTP (0.2 mM of each), upstream 5'-AAGCATACGATGGCCAAAACTTCTGCA-3' and downstream 5' GAACTAGCATTGGAACTTTTCCCAACC-3' primers (3 pmol), 1XTaq Buffer $(75 \mathrm{mM}$ Tris- $\mathrm{HCl} \mathrm{pH}$ 8.8, $20 \mathrm{mM}$ (NH4)2SO4, 0.01\% Tween 20), $2.5 \mathrm{mM}$ $\mathrm{MgCl} 2$ and $1.25 \mathrm{U}$ of Taq DNA polymerase.

Amplification were performed with denaturation for 3 minute at $94^{\circ} \mathrm{C}$, followed by 30 cycles with denaturation for 30 second at $94^{\circ} \mathrm{C}$, annealing for 1 minute at $57^{\circ} \mathrm{C}$, and extension for 1 minute at $72^{\circ} \mathrm{C}$, followed by 5 minute of extension at $72^{\circ} \mathrm{C}(8)$. The PCR products were electrophoresed in $2 \%$ agarose gel, and visualized under UV light transillumination (ETX-F26.M) by ethidium bromide staining. $5 \mu \mathrm{l}$ of PCR product were digested with $5 \mathrm{U}$ 
of the restriction enzyme BsrSI in 1XM Buffer (10 $\mathrm{mM}$ Tris- $\mathrm{HCl} \mathrm{pH} 7.5,10 \mathrm{mM} \mathrm{MgCl} 2,1 \mathrm{mM}$ Dithiothreitol and $50 \mathrm{mM} \mathrm{NaCl}$ ) for 3 hours at $65^{\circ} \mathrm{C}$. When mutant allele (Thymine), digested with BsrSI that yield two fragments $118 \mathrm{bp}$ and $24 \mathrm{bp}$, whereas a wild allele (Cytosine) at nucleotide position 138, had no cutting site for BsrSI, so that the $142 \mathrm{bp} \mathrm{PCR}$ product was not cleaved into $118 \mathrm{bp}$ and $24 \mathrm{bp}$ fragments (8). The restriction digest products were electrophoresed in $3 \%$ agarose gel, and visualized under UV light trans-illumination (ETX-F26.M) by ethidium bromide staining (Figure 3).

\begin{tabular}{llllllll}
\hline 1 & 2 & 3 & 4 & 5 & 6 & $100 \mathrm{bç}$ \\
\end{tabular}

Figure 3. Ethidium bromide-stained 3\% agarose gel of representative PCR digested products of T-138C gene polymorphism shows the TT genotype (118 bp and $24 \mathrm{bp}$ lane 4,5), the CC genotype (142 bp,lane 2) and the CT genotype (142 bp, $118 \mathrm{bp}$ and $24 \mathrm{bp}$, lane 1,3 and 6); lane $100 \mathrm{bp}$ is a size marker.

\section{Statistical Analyses}

Genotype distribution of G-7A and T-138C of Type 2 diabetic patients and control groups were evaluated by Chi-square test ( $\chi 2$ test). Age, fasting blood glucose (FBG), triglyceride (TG), cholesterol, high density lipoprotein cholesterol (HDL-C), low density lipoprotein cholesterol (LDL-C), systolic blood pressure (SBP) and diastolic blood pressure (DBP) were examined by independent student's t-test. The all values are represented as mean \pm standard deviation (SD). Significance was defined as $\mathrm{p}<0.05$

Results

Age, FBG, TG, cholesterol, HDL-C, LDL-C, SBP and DBP of 120 patients with type 2 diabetes mellitus and 134 controls are presented in Table 1. No significant differences were detected between type 2 diabetes mellitus and control groups for TG, SBP, DBP $(p>0.05)$. On the other hand, age, FBG, cholesterol, HDL-C and LDL-C as expected were significantly differed between the patient-control groups $(\mathrm{p}<0.05)$.
Table 1. The clinical characteristics of control and type 2 diabetes mellitus groups

\begin{tabular}{lccc}
\hline & $\begin{array}{c}\text { Control } \\
\text { Group } \\
(\mathbf{n = 1 3 4})\end{array}$ & $\begin{array}{c}\text { Type 2 DM } \\
\text { Group } \\
(\mathbf{n = 1 2 0})\end{array}$ & P \\
\hline Mean Age (Year) & $51.1 \pm 11$ & $62.8 \pm 11$ & 0.001 \\
FBG (mg/dl) & $98.5 \pm 12$ & $169,4 \pm 64$ & 0.001 \\
TG (mg/dl) & $147.4 \pm 91$ & $148.2 \pm 103$ & $\mathrm{~ns}$ \\
CH (mg/dl) & $210.9 \pm 43$ & $179.8 \pm 52$ & 0.001 \\
HDL- C (mg/dl) & $41.2 \pm 11$ & $33.8 \pm 18$ & 0.001 \\
LDL- C (mg/dl) & $130.4 \pm 33$ & $115.7 \pm 42$ & 0.001 \\
SBP (mmHg) & $123.4 \pm 14$ & $125.7 \pm 23$ & $\mathrm{~ns}$ \\
DBP (mmHg) & $76.5 \pm 11$ & $76.1 \pm 13$ & $\mathrm{~ns}$ \\
\hline
\end{tabular}

DM; Diabetes Mellitus NS; not significant, FBG; Fasting blood glucose, TG; Triglyceride; CH; Cholesterol, HDLC; High density lipoprotein cholesterol, LDL-C; Low density lipoprotein cholesterol, SBP; Systolic blood pressure, DBP; Diastolic blood pressure

Genotype frequencies for the G-7A gene polymorphism are presented in Table 2. The overall frequencies of the genotypes AA, GA and GG in type 2 diabetes mellitus group were not significantly differ from those in control group $(\mathrm{p}=0.146)$.

Table 2. Genotype frequencies for the G-7A gene of type 2 diabetes mellitus and control groups.

\begin{tabular}{|c|c|c|c|c|}
\hline & \multicolumn{2}{|c|}{ Group } & \multirow[b]{2}{*}{ Total } & \multirow[b]{2}{*}{$\mathrm{P}$} \\
\hline & $\begin{array}{l}\text { Patient } \\
(\mathrm{n}=120)\end{array}$ & $\begin{array}{l}\text { Control } \\
(\mathrm{n}=134)\end{array}$ & & \\
\hline $\mathrm{AA}$ & $\begin{array}{c}13 \\
(\% 10.8)\end{array}$ & $\begin{array}{c}21 \\
(\% 15.7)\end{array}$ & $\begin{array}{c}34 \\
(\% 13.4)\end{array}$ & \\
\hline GA & $\begin{array}{c}50 \\
(\% 41.7)\end{array}$ & $\begin{array}{c}65 \\
(\% 48.5)\end{array}$ & $\begin{array}{c}115 \\
(\% 45.3)\end{array}$ & 0.146 \\
\hline GG & $\begin{array}{c}57 \\
(\% 47.5)\end{array}$ & $\begin{array}{c}48 \\
(\% 35.8)\end{array}$ & $\begin{array}{c}105 \\
(\% 41.3)\end{array}$ & \\
\hline Total & $\begin{array}{c}120 \\
(\% 100.0)\end{array}$ & $\begin{array}{c}134 \\
(\% 100.0)\end{array}$ & $\begin{array}{c}254 \\
(\% 100.0)\end{array}$ & \\
\hline
\end{tabular}

Genotype frequencies for the $\mathrm{T}-138 \mathrm{C}$ gene polymorphism are presented in Table 3. No differences were detected in alleles ( $\mathrm{C}$ or $\mathrm{T}$ ) frequency between type 2 diabetes mellitus and control groups Our findings, in this patient-control study populating, indicate that the $\mathrm{G}-7 \mathrm{~A}$ and the $\mathrm{T}-138 \mathrm{C}$ gene polymorphisms were not genetic risk factors for type 2 diabetes mellitus

Table 3. Genotype frequencies for the T-138C gene of type 2 diabetes mellitus and control groups

\begin{tabular}{|c|c|c|c|c|}
\hline & \multicolumn{2}{|c|}{ Group } & \multirow[b]{2}{*}{ Total } & \multirow[b]{2}{*}{$\mathrm{P}$} \\
\hline & $\begin{array}{c}\text { Patient } \\
(\mathrm{n}=120)\end{array}$ & $\begin{array}{l}\text { Control } \\
(\mathrm{n}=134) \\
\end{array}$ & & \\
\hline CC & $\begin{array}{c}10 \\
(\% 8.4)\end{array}$ & $\begin{array}{c}5 \\
(\% 3.7)\end{array}$ & $\begin{array}{c}15 \\
(\% 5.9)\end{array}$ & \\
\hline CT & $\begin{array}{c}49 \\
(\% 40.8)\end{array}$ & $\begin{array}{c}53 \\
(\% 39.6)\end{array}$ & $\begin{array}{c}102 \\
(\% \text { 40.2) }\end{array}$ & 0.259 \\
\hline TT & $\begin{array}{c}61 \\
(\% 50.8)\end{array}$ & $\begin{array}{c}76 \\
(\% 56.7)\end{array}$ & $\begin{array}{c}137 \\
(\% 53.9)\end{array}$ & \\
\hline Total & $\begin{array}{c}120 \\
(\% 100.0)\end{array}$ & $\begin{array}{c}134 \\
(\% 100.0)\end{array}$ & $\begin{array}{c}254 \\
(\% 100.0)\end{array}$ & \\
\hline
\end{tabular}




\section{Discussion}

Type 2 diabetes mellitus is characterized by two discrete pathophysiological defects: impaired pancreatic $\beta$-cell function, and insulin resistance in muscle, fat and liver. The prevalence of type 2 diabetes mellitus is increasing dramatically in the world (9). CVD is by far the most common and serious complication of type 2 diabetes mellitus. Increased inflammatory response as lead to insulin resistance and endothelial dysfunction contributes to cardiovascular complications (10).

Individuals with type 2 diabetes mellitus are at least twice as likely to have coronary artery disease compared to non-diabetic individuals, and CVD accounts for $80 \%$ of mortality in type 2 diabetes mellitus patients (11). Increased vascular calcification is associated with an increased risk of cardiovascular events. Type 2 diabetes mellitus is a significant independent risk factor for increased vascular calcification (12). MGP, which is Vitamin K dependent protein that is expressed by smooth muscle cells, fibroblasts, chondrocytes and endothelial cells in a variety of tissues, plays a role in bone metabolism and vascular calcification (13, 14). Several studies identified various candidate genes involved in vascular calcification. MGP plays a key role in the preventing of vascular deposition of the calcium in the matrix $(4,5,15)$.

Many researchers investigated the relationship of vascular calcification and the common gene polymorphisms of the MGP. Two of the most intensively investigated genetic polymorphisms are the G-7A and the T-138C gene polymorphisms. The frequency of the G-7A and the T-138C genotypes and their possible associations with the risk of vascular calcification has been investigated in different populations. Studies of the association of G-7A and the $\mathrm{T}-138 \mathrm{C}$ gene polymorphisms with vascular calcification reported both positive (16) and negative (7) results.

In Ukrainian population, the allelic AA promoter variant of MGP G-7A polymorphism was associated with acute coronary syndrome in males but not in females. However, there was not found any relationship between the $\mathrm{T}-138 \mathrm{C}$ gene polymorphisms with acute coronary syndrome (17). Ataman et al. showed an association for G-7A polymorphism in Ukraine's population. However, they reported that other polymorphic sites such as $\mathrm{T}-138 \mathrm{C}$ do not relate to ischemic stroke (18).

Afshin et al. discovered that the MGP gene starts with the T-138C polymorphism which influences gene expression level; $\mathrm{CC}$ genotype MGP showing the highest levels in blood serum followed by $\mathrm{CT}$ and TT. The $\mathrm{C}$ genotype $(\mathrm{CT}+\mathrm{CC})$ tended to show a higher calcification factor than the TT genotype (8).

In another study, associations between MGP single nucleotide polymorphisms and coronary artery calcification in older men and women of European descent from Massachusetts (USA) were examined.
Various methods of analysis revealed that in men, homozygous carriers of the minor allele of G-7A, T$138 \mathrm{C}$ and $\mathrm{Thr} 83 \rightarrow \mathrm{Ala}$ polymorphisms were associated with a decreased level of coronary artery calcification relative to major allele carriers. This association was not found in women. In addition, genetic variation in MGP was shown to associate with serum MGP concentrations, but there were no association between serum MGP levels and coronary artery calcification (19).

In conclusion, our data do not support any association between G-7A and T-138C gene polymorphisms and type 2 diabetes mellitus disease in this case-control study and is not a determinant for cardiovascular risk factors or complications associated with type 2 diabetes mellitus.

\section{Conclusion}

The determination of the decline in the severity of ED in overall and the complete improvement of ED in some patients after CABS revealed that $\mathrm{CABS}$ had positive impacts on $\mathrm{EF}$ in patients with CAD. Furthermore, the demonstration of a significant improvement in the majority of subgroups of SF in IIEF questionnaire was concluded that CABS had also an encompassing positive impact on almost all domains of sexual function in patients with CAD. On the other hand, the analysis of possible influences of the comorbidities on the impact of CABS on sexual function showed that while the lonely presence of diabetes mellitus did not significantly affected the impact of CABS on sexual function, the sexual function most improved in both diabetic and hypertensive cases after CABS. We supposed that these results need to be confirmed by prospective and randomized trials in greater series.

\section{Conflict of Interest}

The authors declare no potential conflicts of interest with respect to the research, authorship, and/or publication of this article.

\section{Acknowledgements}

The study was supported by the Research Fund of the Trakya University Scientific Research Project (TUBAP).

\section{References}

1. Nowotny K, Jung T, Höhn A, Weber D, Grune T. Advanced Glycation End Products and Oxidative Stress in Type 2 Diabetes Mellitus. Biomolecules 2015;5:194-222.

2. Esen B, Daşdemir S, Çinçin Z, Özdemircan A, Çakmakoğlu B. The Analysis Of Osteoprotegerin (Opg) Protein T950c Gene Polymorphism in Diabetes. İ. Ü. Deneysel Tıp Araştırma Enstitüsü Dergisi. 2011;1(1):40-46.

Metabolik Kemik Hastalıkları. Türkiye Endokrinoloji ve Metabolizma Derneği Dergisi. 2013;19 
4. Tunon-Le Poultel D, Cannata-Andia J. B, Roman-Garcia P, et al. Association of matrix Gla protein gene functional polymorphisms with loss of bone mineral density and progression of aortic calcification. Osteoporos Int 2014;25: 1237-1246.

5. Yoshikawa $\mathrm{K}$, Abe H, Tominaga T, et al. Polymorphism in the human matrix Gla protein gene is associated with the progression of vascular calcification in maintenance hemodialysis patients. Clin Exp Nephrol 2013;17:882-889.

6. Andrea E. Cassidy B, Lawrence F, et al. Matrix Gla Protein Gene Polymorphism Is Associated With Increased Coronary Artery Calcification Progression. Arterioscler Thromb Vasc Biol. 2013;33:645-651.

7. Najafi M, Roustazadeh A, Amirfarhangi A, Kazemi B. Matrix Gla protein (MGP) promoter polymorphic variants and its serum level in stenosis of coronary artery. Mol Biol Rep 2014;41:1779-1786.

8. Farzaneh-Far A, Davies J.D, Braam L, et al A Polymorphism of th Human Matrix _-Carboxyglutamic Acid Protein Promoter Alters Binding of an Activating Protein-1 Complex and Is Associated with Altered Transcription and Serum Levels. The Journal Of Biological Chemistry (C) 2001 by The American Society for Biochemistry and Molecular Biology, Inc. 2001;276(35),32466-32473.

9. Keshavarz P, Inoue H, Sakamoto Y, et al. No evidence for association of the ENPP1 (PC-1) K121Q variant with risk of type 2 diabetes in a Japanese population. J Hum Genet 2006;51:559-566.

10. Keskin Ö. Diabetes Mellitus ve Kardiyovasküler Komplikasyonlar. Kafkas J Med Sci 2011;1(2):81-85.

11. Emral R. Diyabetik Hastalardaki Kardiyovasküler Etkilenimler. Türk Farmakoloji Derneği 21. Ulusal Farmakoloji Kongresi Bildiri Özet Kitabı. 2011;40-42.
12. Demer L.L, Tintut Y. Vascular Calcification Pathobiology of a Multifaceted Disease. Circulation. 2008;117:29382948 .

13. Liabeuf S, Olivier B, Vemeer $\mathrm{C}$, et al. Vascular calcification in patients with type 2 diabetes: the involvement of matrix Gla protein. Liabeuf et al. Cardiovascular Diabetology 2014;13-85.

14. Tavridou A, Petridis I, Vasileiadis M. Association of VKORC1 S1639 G > A polymorphism with carotid intima-media thickness in type 2 diabetes mellitus. Diabetes Research and Clinical Practice 2011;94:236-241.

15. Wang Y, Chen J,Zhang Y, et al. Common Genetic Variants of MGP Are Associated With Calcification on the Arterial Wall but Not With Calcification Present in the Atherosclerotic Plaques. Circ Cardiovasc Genet. 2013;6:271-278

16. Herrmann S.M, Whatling C, Brand E, et al. Polymorphisms of the Human Matrix Gla Protein (MGP) Gene, Vascular Calcification, and Myocardial Infarction. Arterioscler Thromb Vasc Biol. 2000;20:2386-2393.

17. Garbusova V.Y, Gurianova V.L, Stroy D. A, et al. Allelic polymorphism of matrix Gla promoter $\mathrm{G}-7 \rightarrow \mathrm{A}$, but not $\mathrm{T}-$ $138 \rightarrow \mathrm{C}$ nor exon $4 \mathrm{Thr} 83 \rightarrow \mathrm{Ala}$, is positively associated with acute coronary syndrome in the Ukrainian population. Exp Clin Cardiol 2012;17(1):30-33.

18. Ataman A. V, Garbusova V. Y, Ataman Y. A, et al. Investigation of the MGP promoter and exon 4 polymorphisms in patients with ischemic stroke in the Ukrainian population. Journal of Cell and Molecular Biology 2012;10(1):19-26.

19. Crosier M. D, Booth S. L, Peter I, et al. Matrix Gla Protein Are Associated with Coronary Artery Calcification in Men. J Nutr Sci Vitaminol, 2009;55:59-65.

Copyright (C) 2014 The Author(s); This is an open-access article distributed under the terms of the Creative Commons Attribution License (http://creativecommons.org/licenses/by/4.0), which permits unrestricted use, distribution, and reproduction in any medium, provided the original work is properly cited. All Rights reserved by international journal of Medical Science and Discovery and Lycians Press Inc. 